\title{
One-step DNA Fragment Assembly and Circularization for Gene Cloning
}

\author{
Peijun Zuo* and A. Bakr M. Rabie
}

Orthodontics, Faculty of Dentistry, The University of Hong Kong, 2/F, Prince Philip Dental Hospital, 34 Hospital Road, Hong Kong, China

\begin{abstract}
This article describes a one-step procedure based on Taq polymerase for the precise assembly of DNA fragments into circular constructs as long as $6 \mathrm{~kb}$. The only prior step needed was the amplification of the gene to be cloned and the linear vector backbone, and the whole process up to assembly and circularization lasted only 2 days, compared with the conventional method's 2 weeks. Furthermore, the final DNA construct was used to transform Escherichia coli directly without any further treatment. By circumventing the need for DNA ligase, our "Quick Assemble" method offers an improvement over the combination of long PCR and overlap extension PCR, and is expected to facilitate various kinds of complex genetic engineering projects that require precise in-frame assembly of multiple fragments, such as multiple site-directed mutagenesis and whole-DNA library gene shuffling, as well as the construction of new plasmids with any promoter, resistance gene marker, restriction site, or any DNA tag.
\end{abstract}

\section{Introduction}

Recombinant DNA projects generally involve the ligation of two or more long fragments of DNA, but this process is sometimes not possible with conventional cloning techniques, or unwanted sequences need to be inserted first (Shevchuk et al. 2004). Several alternative approaches have been developed, but they usually require the use of a single-stranded DNA template (Kunkel 1985 ), which must be pre-prepared from double-stranded DNA. One method not requiring single-stranded DNA is DNA shuffling, in which pools of selected mutant genes are randomly fragmented and reassembled by in vitro homologous recombination, followed by the polymerase chain reaction (PCR) (Stemmer 1994). Some other ligase-free cloning methods need to use either topoisomerase I (Heyman et al. 1999) or uracil DNA glycosylase (Rashtchian et al. 1992; Buchman et al. 1993). Both of them need special vectors. Another method is overlap extension PCR. For example, Shuldiner et al developed a PCR-induced (ligase-free) subcloning method (Shuldiner et al. 1990; Shuldiner et al. 1991). However, the PCR protocols are still limited by existing techniques of DNA purification to remove excess primers through an Utrafree-MC unit. The exact steps contain 1) PCR amplification from genomic DNA or cDNA, 2) Filtration to remove excess primers, 3) Two sets of PCR reactions with 2 sets primers, "ac" and "bd", 4) Combine 2 sets of PCR products and cyclization. 5) Concentrating the mixture. It is labor-intensive.

"Corresponding author: Email: pzuo@hkucc.hku.hk
In this article, we describe a modified PCR method that simultaneously and precisely anneals and ligates DNA fragments, thereby allowing recombinant products to be created in fewer steps than conventional restriction enzyme cloning. We have demonstrated this one-step method of DNA fragment assembly and circularization by successfully inserting the mouse alpha-synuclein gene into a vector based on the plasmid pcDNA3.1/N5-His-TOPO. This method contains 1) PCR amplification from genomic DNA or cDNA, 2) circularization of PCR product and linear plasmid. The PCR product can be used directly in the circularization without any purification. The circularization step does not need to add any primers.

\section{Material and Methods \\ Cell Culture}

Mouse ATDC5 cells, from an embryonal carcinoma-derived chondrogenic cell line, were cultured in a 1:1 mixture of Dulbecco's modified Eagle's medium and Ham's F-12 medium (Flow Laboratories, Irvine, UK) containing 5\% fetal bovine serum (GIBCO BRL, Gaithersburg, MD), $100 \mathrm{U} /$ $\mathrm{mL}$ penicillin, and $100 \mu \mathrm{g} / \mathrm{mL}$ streptomycin (Biofluids Inc., Rockville, MD, USA), and incubated at $37^{\circ} \mathrm{C}$ in a humidified atmosphere containing $5 \%$ carbon dioxide. An inoculum of cells $\left(3 \times 10^{5}\right.$ cells in $30 \mathrm{~mL}$ of medium) was transferred to each of 7 Petri dishes. Lead nitrate was added to reach a final concentration of $200 \mu \mathrm{mol} / \mathrm{L}$ per plate to stimulate alpha-synuclein transcription, and glutamic acid was added to reach a concentration of $200 \mu \mathrm{mol} / \mathrm{L}$ to increase the solubility of the lead nitrate. The cells were harvested at 48 hours.

\section{Generation of cDNA Pool}

Total RNA was isolated from cells with an RNeasy Mini Kit (Qiagen Sciences, Germantown, MD). Reverse transcription of the mRNA to generate the cDNA pool was performed with oligo-(dT) primers and Moloney murine leukemia virus reverse transcriptase (Applied Biosystems, Foster City, CA).

\section{Production of DNA Fragments}

The linear vector backbone of pcDNA3.1/V5-His-TOPO was produced by high-fidelity PCR amplification of the circular plasmid pcDNA3.1/V5-His-TOPO (Invitrogen, Carlsbad, USA) using the forward primer of 5 '-aag ggc aat tct gca gat atc cag $c-3^{\prime}$ (melting temperature, $T m=60.6^{\circ} \mathrm{C}$ ) and reverse primer of 5'-AAG GGC AAT TCC ACC ACA CTG GAC-3' $\left(\mathrm{Tm}=61.9^{\circ} \mathrm{C}\right)$. Each $50-\mu \mathrm{L}$ sample in the PCR thermocycler (Takara Bio, Shiga, Japan) contained $5 \mu \mathrm{L} 10 \times$ AccuPrime $^{\mathrm{TM}}$ PCR Buffer I (Invitrogen), $1 \mu \mathrm{L}$ of each primer at $10 \mu \mathrm{M}, 40$ ng of circular pcDNA3.1/V5-His-TOPO, and 0.2 $\mu \mathrm{L}$ Taq DNA polymerase (AccuPrime ${ }^{\mathrm{TM}}$ Taq High Fidelity; Invitrogen). The mouse alpha-synuclein gene was amplified from the cDNA pool from ATDC5 cells by high-fidelity PCR using the forward primer 5 '-gtc cag tgt ggt gga att gcc ctt acc atg gat gtg ttc atg aaa gga ctt tca aag-3' (the Kozak consensus 
sequence is underlined and the overlapping sequence with the vector is bolded) and reverse primer 5'-GCT GGA TAT CTG CAG AAT TGC CCT TTT AGG CTT CAG GCT CAT AGT CTT GGT AGC-3'. Each $50-\mu \mathrm{L}$ sample in the PCR thermocycler contained $5 \mu \mathrm{L} 10 \times$ AccuPrime $^{\mathrm{TM}}$ PCR Buffer I, $1 \mu \mathrm{L}$ of each primer at $10 \mu \mathrm{M}, 40 \mathrm{ng}$ of CDNA derived from ATDC5 cells, and $0.2 \mu \mathrm{L}$ AccuPrime ${ }^{\mathrm{TM}}$ Taq High Fidelity. The PCR cycling profile for all reactions was as follows: $94^{\circ} \mathrm{C}$ for 2 minutes, $94^{\circ} \mathrm{C}$ for 30 seconds, $52^{\circ} \mathrm{C}$ for 30 seconds, and $68^{\circ} \mathrm{C}$ for 3 minutes (for 35 cycles); the holding temperature was $4^{\circ} \mathrm{C}$.

\section{Assembly of DNA Fragments}

Single-step DNAassembly and circularization was performed on non-purified PCR amplification products by high-fidelity PCR, simply by adding more Taq DNA polymerase. Each $50-\mu \mathrm{L}$ sample contained $5 \mu \mathrm{L} 10 \times$ AccuPrime $^{\mathrm{TM}} \mathrm{PCR}$ Buffer $\mathrm{I}, 0.5 \mu \mathrm{L}$ of raw reaction product mix containing the linear vector backbone, $2 \mu \mathrm{L}$ of raw reaction product mix including the alpha-synuclein gene, and $0.2 \mu \mathrm{L}$ AccuPrime ${ }^{\mathrm{TM}} \mathrm{Taq}$ High Fidelity. The ratios of insert to vector were 4: 1 . This ratio should change based on the size of the fragments. But for the insert range of $500 \mathrm{bp}$ to $2000 \mathrm{bp}$, the ratios of insert to vector kept in 4:1 were worked well. The PCR cycling profile was as follows: $94^{\circ} \mathrm{C}$ for 2 minutes, $94^{\circ} \mathrm{C}$ for 30 seconds, $52^{\circ} \mathrm{C}$ for 30 seconds, and $68^{\circ} \mathrm{C}$ for 3 minutes (for 35 cycles); the holding temperature was $4^{\circ} \mathrm{C}$. Because the primers included complementary directional overhangs, the correct head and tail sequences of the vector and gene were expected to anneal and assemble into plasmid pcDNA3.1/ V5-His-TOPO-alpha-synuclein (Figure 1).

\section{Transformation Procedure}

One tube of $50 \mu \mathrm{L}$ DH5a Escherichia coli cells was thawed on ice and $1 \mu \mathrm{L}$ of raw reaction product mix from the previous step, which contained the assembled DNA construct, was immediately added and mixed gently. The tube was then incubated on ice for 30 minutes, heated for 60 seconds in a $42^{\circ} \mathrm{C}$ water bath, and placed on ice for 2 minutes. The contents were added to $950 \mu \mathrm{L}$ of pre-warmed SOC medium ( $2 \%$ tryptone, $0.5 \%$ yeast extract, $0.05 \% \mathrm{NaCl}, 2.5 \mathrm{mM} \mathrm{KCl}$, $20 \mathrm{mM}$ glucose) in a 1.5-mL tube and shaken at a speed of $225 \mathrm{rpm}$ at $37^{\circ} \mathrm{C}$ for 1 hour. Finally, $200 \mu \mathrm{L}$ was spread onto a pre-warmed LB agar plate containing $100 \mu \mathrm{g} / \mathrm{mL}$ ampicillin, and the plate was incubated overnight at $37^{\circ} \mathrm{C}$.

\section{Plasmid DNA Extraction}

A colony of transformed $E$. coli cells was picked and grown in $5 \mathrm{~mL} \mathrm{LB}$ medium at $37^{\circ} \mathrm{C}$ overnight. Plasmid DNA was extracted with the Plasmid Miniprep Kit (Sigma-Aldrich, St. Louis, MO).

\section{Restriction Enzyme Digestion}

Double digestion was performed on a sample of extracted plasmid DNA with HindIII $(20,000 \mathrm{U} / \mathrm{mL}$, New England Biolabs, Ipswich, MA) and Xhol (10,000 U/mL, New England Biolabs). The two restriction sites were just beyond the gene either side (Figure 1). Digestion products were subjected to agarose gel electrophoresis to determine the size of the inserted fragment.

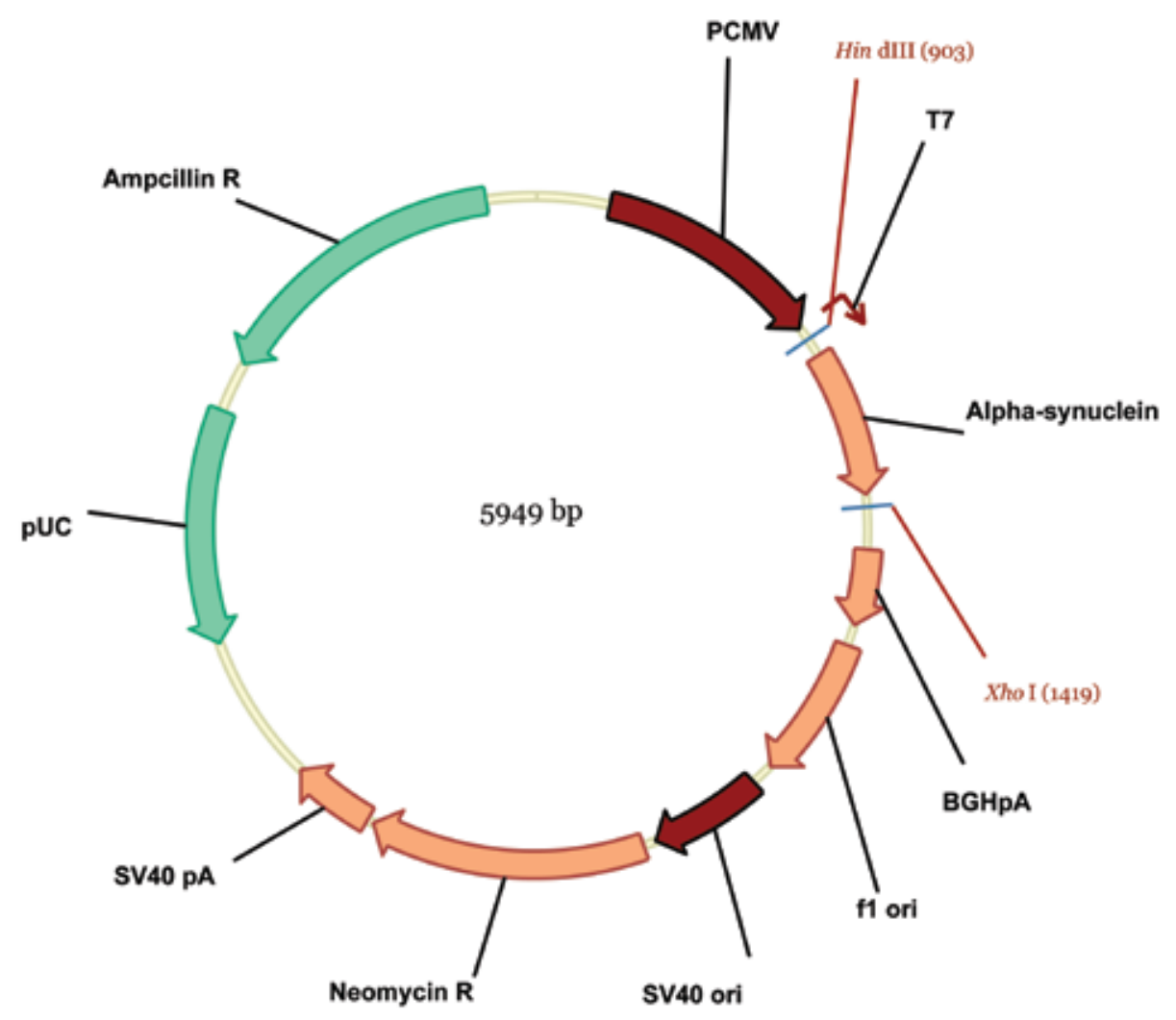

Figure 1. Diagram of plasmid pcDNA3.1/V5-His-TOPO-alpha-synuclein. Plasmid pcDNA3.1/V5-His-TOPO and mouse gene alpha-synuclein were amplified separately, and complementary head and tail sequences allowed directional self-assembly. 


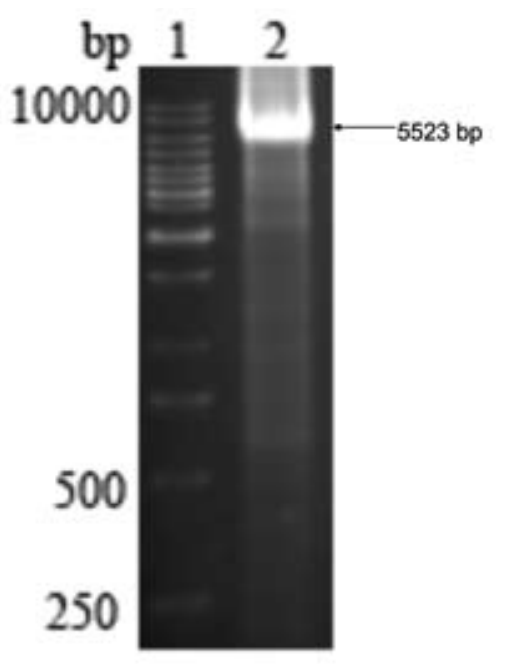

Figure 2. Amplification of linear backbone pcDNA3.1/V5His-TOPO. Plasmid pcDNA3.1/V5-His-TOPO was amplified by the polymerase chain reaction using AccuPrime ${ }^{\mathrm{TM}}$ Taq High Fidelity polymerase. Lane 1: DNA molecular weight markers. Lane 2: amplified linear pcDNA3.1/V5-His-TOPO (5523 bp).

\section{Western Blot}

Complexes between pcDNA3.1/V5-His-TOPO-alphasynuclein Lipofectamine ${ }^{\mathrm{TM}} 2000$ Transfection Reagent (Invitrogen) were prepared according to the particular specifications of the manufacturer. Generally, afterpcDNA3.1/ V5-His-TOPO-alpha-synuclein-reagent complexes had formed, the mixture was exposed to cultures and incubated for $6 \mathrm{~h}$ before replacing the Dulbecco's modified Eagle's medium and Ham's F-12 medium. Lipofectamine ${ }^{\mathrm{TM}} 2000$

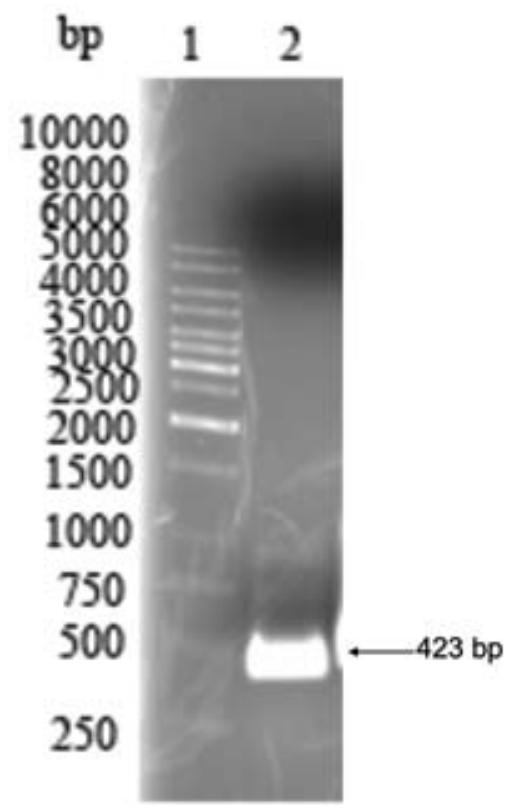

Figure 3. Amplification of the mouse alpha-synuclein gene. Alpha-synuclein was amplified by the polymerase chain reaction using AccuPrime ${ }^{\mathrm{TM}}$ Taq High Fidelity polymerase. Lane 1: DNA molecular weight markers. Lane 2: amplified linear alpha-synuclein gene (423 bp).
Transfection Reagent was used as per guidelines for 6 -well plates with a volume of $10 \mu \mathrm{l}$ per well. The cells were immediately scraped off the plate after $48 \mathrm{~h}$ incubated at $37^{\circ} \mathrm{C}$ in a humidified atmosphere containing $5 \%$ carbon dioxide. The sample was sonicated for $10-15$ seconds to shear DNA and reduce sample viscosity. An aliquot of cell extract (15 $\mu \mathrm{g}$ of cytosolic soluble proteins) was used for determining alpha-synuclein protein content by purified mouse anti-alpha-synuclein antibody (BD Transduction Laboratories).

\section{Sequencing}

Sequencing of the final plasmid construct was performed by the Genome Research Centre, The University of Hong Kong, with the $A B I$ BigDye sequencing method, according to the manufacturer's instructions (Applied Biosystems, Foster City, CA).

\section{Results}

Linear backbone of pcDNA3.1/N5-His-TOPO

As revealed by agarose gel electrophoresis, linear pcDNA3.1/V5-His-TOPO was produced by high-fidelity PCR from circular pcDNA3.1/V5-His-TOPO in sufficient quantity and was the expected size of 5523 bp (Figure 2).

\section{Mouse alpha-synuclein}

The mouse alpha-synuclein gene that was amplified from mouse cDNA was the expected size of 423 bp (Figure 3).

The assembly product

For assembly both vector and insert, the quantities of vector and insert were $234.6 \mathrm{ng}$ and $938.4 \mathrm{ng}$, respectively. The concentration of vector and insert were determined by spectrophotometer at $\lambda_{260}$. The idle ratios of the insert to vector were expected that both the vector and insert are completely assembly together. However, the ratios were not significant from $10: 1$ to $4: 1$. We used the ratios as $4: 1$. Both the linear vector pcDNA3.1/V5-His-TOPO and amplified

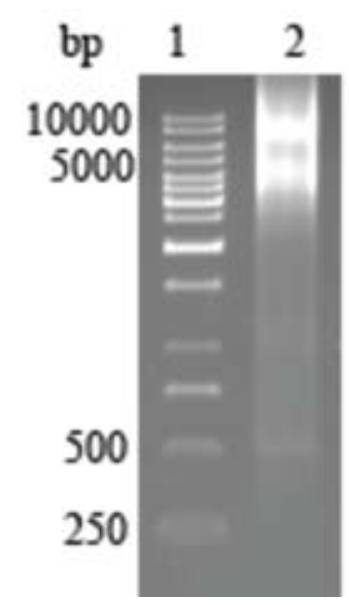

Figure 4. Circularization of fragments. Amplified linear pcDNA3.1/V5-His-TOPO and alpha-synuclein were joined and circularized by the polymerase chain reaction using AccuPrime $^{\mathrm{TM}}$ Taq High Fidelity polymerase. Lane 1: DNA molecular weight markers. Lane 2: circularization products of pcDNA3.1/V5-His-TOPO and alpha-synuclein. 


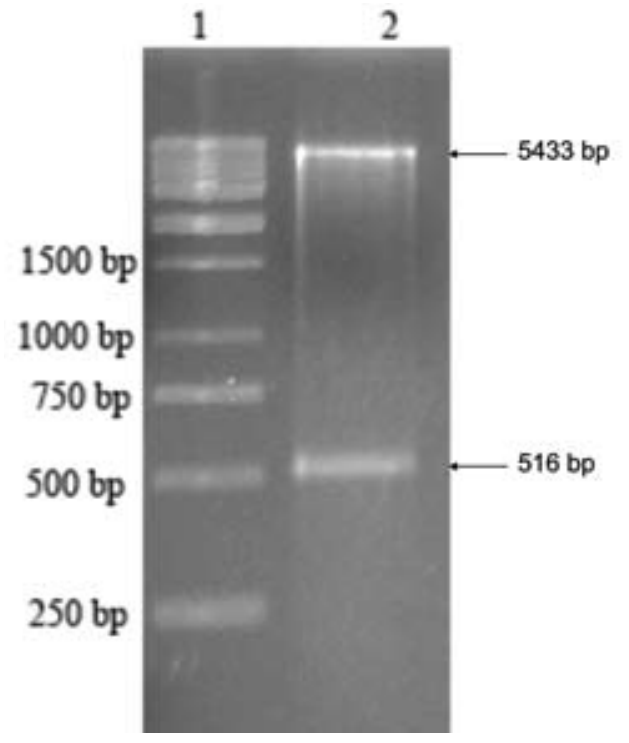

Figure 5. Confirmation of assembled plasmid pcDNA3.1/ V5-His-TOPO-alpha-synuclein. The pcDNA3.1/V5-HisTOPO-alpha-synuclein plasmid was cleaved by HindIII and Xhol. Lane 1: DNA molecular weight markers. Lane 2: Two digestion fragments of $5433 \mathrm{bp}$ and $516 \mathrm{bp}$.

alpha-synuclein gene annealed and ligated together during PCR using DNA polymerase. The raw assembly product was a mixture of circular DNA molecules that ranged in size from $500 \mathrm{bp}$ to more than 10,000 bp (Figure 4). Because we added ACC before the start site in the alpha-synuclein gene to generate the Kozak consensus sequence (to assist in the initiation of translation), the exact size of the desired plasmid containing the vector and gene was expected to be 5949 bp.

After transformation of $E$. coli, only cells hosting intact pcDNA3.1/V5-His-TOPO-alpha-synuclein plasmids could grow on LB plates containing ampicillin. The others still kept in liner form were not grown at all. Using this method, we got 7 colonies per transformation (transformation efficiency was $1.864 \times 10^{2}$ colonies per microgram of PCR insert). We picked up 3 colonies. One of them contained the $423 \mathrm{bp}$ insert. The other 2 contained inserts of different sizes (250

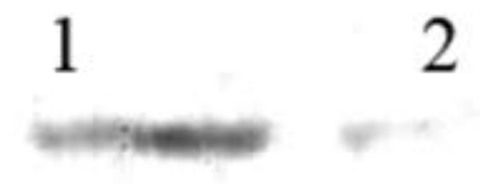

Figure 6. Western blot of assembled plasmid pcDNA3.1/V5His-TOPO-alpha-synuclein. The pcDNA3.1/V5-His-TOPOalpha-synuclein plasmid was transfected to mouse ATDC5 cells. Lane 1: pcDNA3.1/V5-His-TOPO-alpha-synuclein plasmid was transfected to mouse ATDC5 cells. Lane 2: pcDNA3.1/V5-His-TOPO empty vector was transfected to mouse ATDC5 cells. bp and $1000 \mathrm{bp}$ ). Double digestion of extracted plasmid DNA with HindlII and Xhol yielded two fragments on a $1 \%$ agarose gel, of sizes $5433 \mathrm{bp}$ and $516 \mathrm{bp}$, representing linear vector pcDNA3.1/V5-His-TOPO and alpha-synuclein gene, respectively (Figure 5 ). We also performed a western blot proving that the gene was functional (Figure 6). The pcDNA3.1/V5-His-TOPO-alpha-synuclein expressed more alpha-synuclein protein in ATDC5 cells than the control empty pcDNA3.1/V5-His-TOPO. These findings indicated that mouse alpha-synuclein had been successfully inserted into pcDNA3.1/V5-His-TOPO and cloned.

\section{Sequencing}

The DNA sequence of the complete pcDNA3.1/V5-HisTOPO-alpha-synuclein construct was $100 \%$ in agreement with the sequences of the two constituent DNA fragments (data not shown).

\section{Discussion}

In conventional gene cloning, suitable restriction enzymes need to be identified before genes can be inserted into a vector plasmid. Both vector plasmid DNA and gene insert are typically cut with the same restriction enzyme(s) and then ligated together with DNA ligase (Russell and Sambrook 2001). However, the gene may sometimes contain internal restriction sites that are also recognized by the chosen enzyme, and these require prior deletion by site-directed mutagenesis. Many approaches to do this are available, because site-directed mutagenesis is widely used to study protein function. An oligonucleotide-based method was developed by Michael Smith, who was awarded a Nobel Prize in 1993 for this contribution (Zoller and Smith 1987). There are also methods based on PCR. Stemmer et al. used DNA shuffling to synthesize both strands of the promoter and structural regions of the bla gene from 56 individual oligonucleotides. Those researchers introduced five point mutations to create five new restriction sites to differentiate the synthetic gene from the naturally occurring bla gene (Stemmer et al. 1995). However, a shortcoming of current PCR protocols, including long PCR and overlap extension PCR, is the time and resources needed for DNA purification, digestion, and ligation.

Our "Quick Assemble" method requires only 2 days to construct the final plasmid, compared with the conventional method's 2 weeks. Shuldiner et al. reported their work to subclone polymerase chain reaction products in a single day (Shuldiner et al. 1990; Shuldiner et al. 1991). Their method is more complicated than ours. It contains 5 steps. 1) PCR amplification from genomic DNA or CDNA, 2) Filtration to remove excess primers, 3) Two sets of $P C R$ reactions with 2 sets primers, "ac" and "bd", 4) Combine 2 sets of PCR products and cyclization. 5) Concentrating the mixture. It is labor-intensive.

Our method contains only 2 steps. They are 1) PCR amplification from genomic DNA or cDNA and linear plasmid, 2) circularization of PCR product and linear plasmid. There is no reason our method need 1 day more than Shuldiner's method. The stop point for us is getting the $E$. coli colonies which hosted the recombinant plasmid. For sure, Shuldiner's method needs 2 days if they set the end point as getting the colonies. First, in our method, the individual parts of the desired construct are separately generated by PCR as linear DNA fragments. Then, the PCR products, which do 

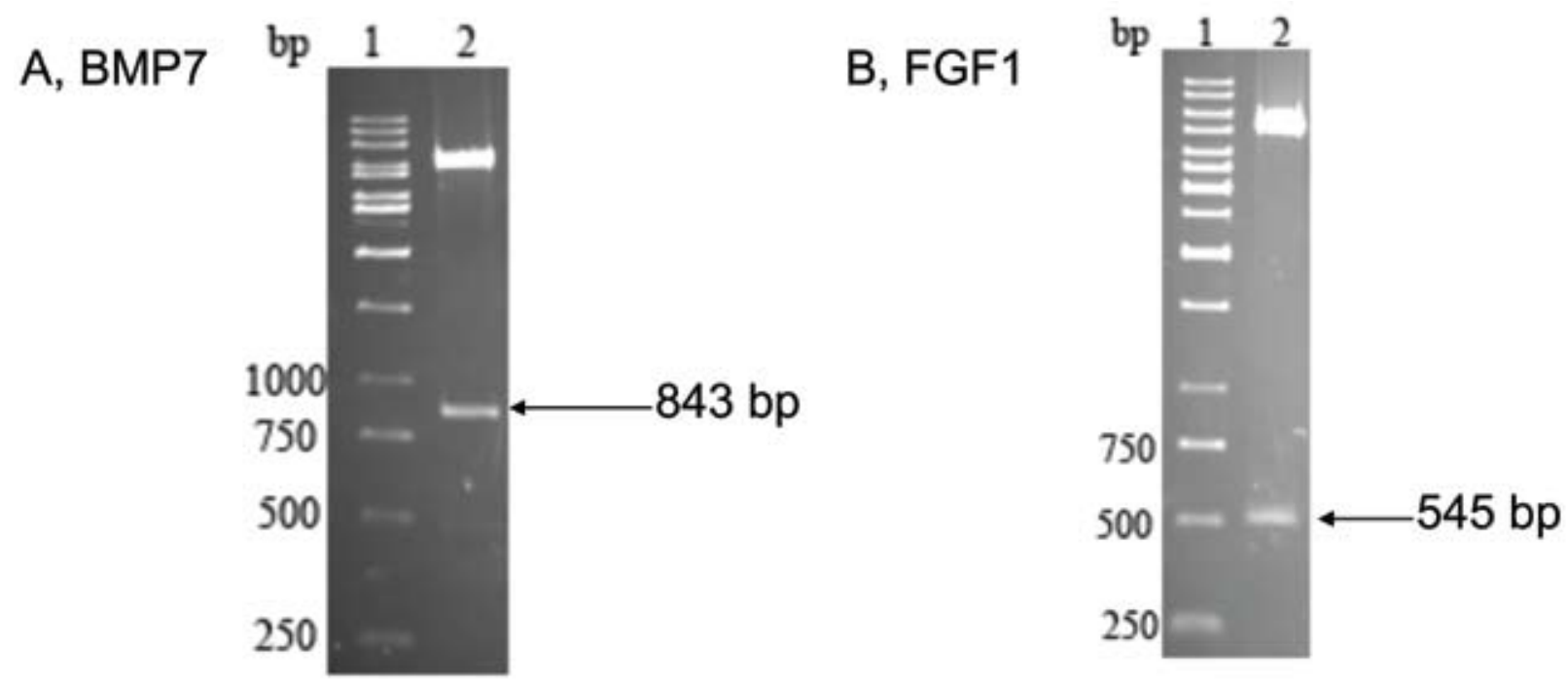

Figure 7. Confirmation of assembled plasmid pcDNA3.1/V5-His-TOPO-BMP7 and pcDNA3.1/V5-His-TOPO-FGF1.The pcDNA3.1/V5-His-TOPO-BMP7 and pcDNA3.1/V5-His-TOPO-FGF1 plasmids were cleaved by Kpnl and Notl. A, Lane 1: DNA molecular weight markers. Lane 2: The size of BMP7 was 843bp. B, Lane 1: DNA molecular weight markers. Lane 2: The size of FGF1 was $545 \mathrm{bp}$.

not need be gel extracted or purified, are directly assembled together in one PCR tube together with buffer and DNA polymerase without any primers. Owing to the directional complementary overhangs in the fragments and their large combined length (about $6 \mathrm{~kb}$ ), the next PCR step allows annealing and intramolecular ligation of the plasmid without the need for DNA ligase. During single stranded melting, PCR created the complete second strand. Furthermore, we have shown that the circularized final plasmid can be cloned via $E$. coli transformation, again without any additional treatment, gel extraction, or purification.

For check the repeatability of this method, 2 other genes, bone morphogenetic protein 7 (BMP7), and human fibroblast growth factor 1 (FGF1) were cloned into vector pcDNA3.1/ V5-His-TOPO (Figure 7). Both the recombinant vectors were confirmed by the insert size generated by restriction enzyme Kpnl and Notl digestion and the sequences.

Our new 2-day PCR-based method could be used to generate both circularized and linear final assembled products. Smith et al. have recently described techniques of synthesizing approximately 5-kb segments of DNA, followed by their assembly into longer sequences by conventional cloning methods (Smith et al. 2003). The size of the synthesized DNA can reach 31,656 bp (Kodumal et al. 2004). Our method could make the synthesis and assembly of these large molecules in a quick and efficient way, while circumventing the use of DNAligases. Our ligase-free method also offers an additional improvement over the combination of long PCR and overlap extension PCR, and is expected to facilitate various kinds of complex genetic engineering projects that require precise in-frame assembly of multiple fragments, such as multiple site-direct mutagenesis and whole-DNA library gene shuffling. In addition, new restriction sites could be created. We have recently deleted 2 Pvull restriction sites in the pUC19 plasmid with this technique $(P$. Zuo and J. Tian, 2007, unpublished data).
"TA cloning" is a popular method of cloning without the use of restriction enzymes; instead, PCR products are amplified with only Taq DNA polymerase and other polymerases. These polymerases lack 5'-3' proofreading activity and add an adenosine triphosphate residue to the $3^{\prime}$ ends of the double-stranded PCR products. Such PCR amplified products can thus be cloned in a linearized vector that has complementary 3' thymidine triphosphate overhangs. The major problem is that the gene has a $50 \%$ chance of getting cloned in the reverse direction. The method also needs DNA ligase. The vector pcDNA3.1/V5-His-TOPO is a plasmid used in TA cloning (Tekin et al. 2006), and we used it as the template for the linear vector backbone in our protocol, implying that our "Quick Assemble" technique could also be applied to improve TA cloning.

The number of vectors in molecular cloning is continually growing and the correct vector must be carefully chosen to match the purpose of the research. However, for some projects no vector will be suitable. With our protocol, any kind of vector, or even any part(s) of a vector, could be assembled together and used as a template to generate any vector backbone for gene insertion without the need for ligase. Our new method would hence allow the construction of new, tailor-made plasmids to fulfill a variety of needs. The following reporter genes could conceivably be constructed:

1) Green fluorescent protein that fluoresces green when exposed to blue light (Prendergast and Mann 1978) or ultraviolet light (Tsien 1998);

2) Red fluorescent protein (Campbell et al. 2002);

3) $\beta$-Galactosidase that reacts to substrates of different $\beta$-galactosidases, including ganglioside GM1, lactosylceramides, lactose, and various glycoproteins (Matthews 2005);

4) Luciferase (from lightening bugs) (Greer and Szalay 2002); 
5) Chloramphenicol acetyltransferase (from bacteria) (Leslie et al. 1988);

6) $\beta$-Glucuronidase commonly used in plants (Wynn et al. 1981).

Alternatively, our new method could attach reporter or other tags to a targeted gene. For example, polyhistidine tags are often added to allow the affinity purification of polyhistidinetagged recombinant proteins after expression in $E$. coli (Hengen 1995). Human immunoglobulin Fc fragment, maltose-binding protein, glutathione S-transferase, and thioredoxin could also function as tags when fused with target genes (Xu et al. 2008). Furthermore, our method would enable researchers to replace promoters or modify resistance to antibiotics by using different or multiple resistance gene markers such as ampicillin, kanamycin, neomycin, chloramphenicol, gentamycin, tetracycline, erythromycin, streptomycin, vancomycin, and spectinomycin (Wang et al. 2009).

In summary, we describe a new one-step "Quick Assemble" method of precisely and simultaneously joining multiple DNA fragments followed by intramolecular ligation. This technique of plasmid assembly and circularization could be used to easily construct new plasmids with any promoter, resistance gene marker, restriction site, or tag. In the future, DNA shuffling might become easier and quicker with this method to offer new opportunities in genetic engineering.

\section{Acknowledgement}

We thank Dr. Trevor Lane for kindly editing the manuscript.

\section{References}

Buchman GW, Schuster DM, Rashtchian A (1993). Selective RNA amplification: a novel method using dUMP-containing primers and uracil DNA glycosylase. PCR Methods Appl. 3, 28-31.

Campbell RE, Tour O, Palmer AE, Steinbach PA, Baird GS, Zacharias DA, Tsien RY (2002). A monomeric red fluorescent protein. Proc Natl Acad Sci U S A. 99, 7877-7882.

Greer LF, 3rd, Szalay AA (2002). Imaging of light emission from the expression of luciferases in living cells and organisms: a review. Luminescence. 17, 43-74.

Hengen P (1995). Purification of His-Tag fusion proteins from Escherichia coli. Trends Biochem Sci. 20, 285-286.

Heyman JA, Cornthwaite J, Foncerrada L, Gilmore JR, Gontang E, Hartman KJ, Hernandez CL, Hood R, Hull HM, Lee WY, Marcil R, Marsh EJ, Mudd KM, Patino MJ, Purcell TJ, Rowland JJ, Sindici ML, Hoeffler JP (1999). Genome-scale cloning and expression of individual open reading frames using topoisomerase I-mediated ligation. Genome Res. 9, 383-392.

Kodumal SJ, Patel KG, Reid R, Menzella HG, Welch M, Santi DV (2004). Total synthesis of long DNA sequences: synthesis of a contiguous 32-kb polyketide synthase gene cluster. Proc Natl Acad Sci U S A. 101, 15573-15578.

Kunkel T (1985). Rapid and efficient site-specific mutagenesis without phenotypic selection. Proc Natl Acad Sci U S A. 82, 488-492.
Leslie AG, Moody PC, Shaw WV (1988). Structure of chloramphenicol acetyltransferase at $1.75-\mathrm{A}$ resolution. Proc Natl Acad Sci U S A. 85, 4133-4137.

Matthews BW (2005). The structure of $E$. coli betagalactosidase. C R Biol. 328, 549-556.

Prendergast FG, Mann KG (1978). Chemical and physical properties of aequorin and the green fluorescent protein isolated from Aequorea forskalea. Biochemistry. 17, 3448-3453.

Rashtchian A, Buchman GW, Schuster DM, Berninger MS (1992). Uracil DNA glycosylase-mediated cloning of polymerase chain reaction-amplified DNA: application to genomic and cDNA cloning. Anal Biochem. 206, 91-97.

Russell DW, Sambrook J (2001). Molecular cloning: a laboratory manual. N.Y: Cold Spring Harbor.

Shevchuk NA, Bryksin AV, Nusinovich YA, Cabello FC, Sutherland M, Ladisch S (2004). Construction of long DNA molecules using long PCR-based fusion of several fragments simultaneously. Nucleic Acids Research. 32, e19.

Shuldiner AR, Scott LA, Roth J (1990). PCR-induced (ligasefree) subcloning: a rapid reliable method to subclone polymerase chain reaction (PCR) products. Nucleic Acids Res. 18, 1920.

Shuldiner AR, Tanner K, Scott LA, Moore CA, Roth J (1991). Ligase-free subcloning: a versatile method to subclone polymerase chain reaction (PCR) products in a single day. Anal Biochem. 194, 9-15.

Smith HO, Hutchison CA, 3rd, Pfannkoch C, Venter JC (2003). Generating a synthetic genome by whole genome assembly: phiX174 bacteriophage from synthetic oligonucleotides. Proc Natl Acad Sci U S A. 100, $15440-15445$.

Stemmer W (1994). Rapid evolution of a protein in vitro by DNA shuffling. Nature. 370, 389-391.

Stemmer WPC, Crameri A, Ha KD, Brennan TM, Heyneker HL (1995). Single-step assembly of a gene and entire plasmid from large numbers of oligodeoxyribonucleotides. Gene. 164, 49-53.

Tekin S, Padua MB, Brad AM, Rhodes ML, Hansen PJ (2006). Expression and properties of recombinant ovine uterine serpin. Exp Biol Med (Maywood). 231, 1313-1322.

Tsien RY (1998). The green fluorescent protein. Annu Rev Biochem. 67, 509-544.

Wang Z, Jin L, Yuan Z, Wegrzyn G, Wegrzyn A (2009). Classification of plasmid vectors using replication origin, selection marker and promoter as criteria. Plasmid. 61, 47-51.

Wynn CH, Nathoo V, Hambrey PN (1981). The heterogeneous distribution of beta-glucuronidase in purified Golgi membranes. Biosci Rep. 1, 865-871.

Xu ZW, Zhang T, Song CJ, Li Q, Zhuang R, Yang K, Yang AG, Jin BQ (2008). Application of sandwich ELISA for detecting tag fusion proteins in high throughput. Appl Microbiol Biotechnol. 81, 183-189.

Zoller MJ, Smith M (1987). Oligonucleotide-directed mutagenesis: a simple method using two oligonucleotide primers and a single-stranded DNA template. Methods Enzymol. 154, 329-350. 


\section{Further Reading}

Caister Academic Press is a leading academic publisher of advanced texts in microbiology, molecular biology and medical research. Full details of all our publications at caister.com

- MALDI-TOF Mass Spectrometry in Microbiology Edited by: M Kostrzewa, S Schubert (2016) www.caister.com/malditof

- Aspergillus and Penicillium in the Post-genomic Era Edited by: RP Vries, IB Gelber, MR Andersen (2016) www.caister.com/aspergillus2

- The Bacteriocins: Current Knowledge and Future Prospects Edited by: RL Dorit, SM Roy, MA Riley (2016)

www.caister.com/bacteriocins

- Omics in Plant Disease Resistance Edited by: V Bhadauria (2016) www.caister.com/opd

- Acidophiles: Life in Extremely Acidic Environments Edited by: R Quatrini, DB Johnson (2016) www.caister.com/acidophiles

- Climate Change and Microbial Ecology: Current Research and Future Trend

Edited by: J Marxsen (2016)

www.caister.com/climate

- Biofilms in Bioremediation: Current Research and Emerging Technologies

Edited by: G Lear (2016)

www.caister.com/biorem

- Microalgae: Current Research and Applications Edited by: MN Tsaloglou (2016) www.caister.com/microalgae

- Gas Plasma Sterilization in Microbiology: Theory, Applications, Pitfalls and New Perspectives Edited by: H Shintani, A Sakudo (2016) www.caister.com/gasplasma

- Virus Evolution: Current Research and Future Directions Edited by: SC Weaver, M Denison, M Roossinck, et al. (2016) www.caister.com/virusevol

- Arboviruses: Molecular Biology, Evolution and Control Edited by: N Vasilakis, DJ Gubler (2016) www.caister.com/arbo

- Shigella: Molecular and Cellular Biology Edited by: WD Picking, WL Picking (2016) www.caister.com/shigella

-Aquatic Biofilms: Ecology, Water Quality and Wastewater Treatment

Edited by: AM Romaní, H Guasch, MD Balaguer (2016)

www.caister.com/aquaticbiofilms

- Alphaviruses: Current Biology

Edited by: S Mahalingam, L Herrero, B Herring (2016)

www.caister.com/alpha

- Thermophilic Microorganisms

Edited by: F Li (2015)

www.caister.com/thermophile
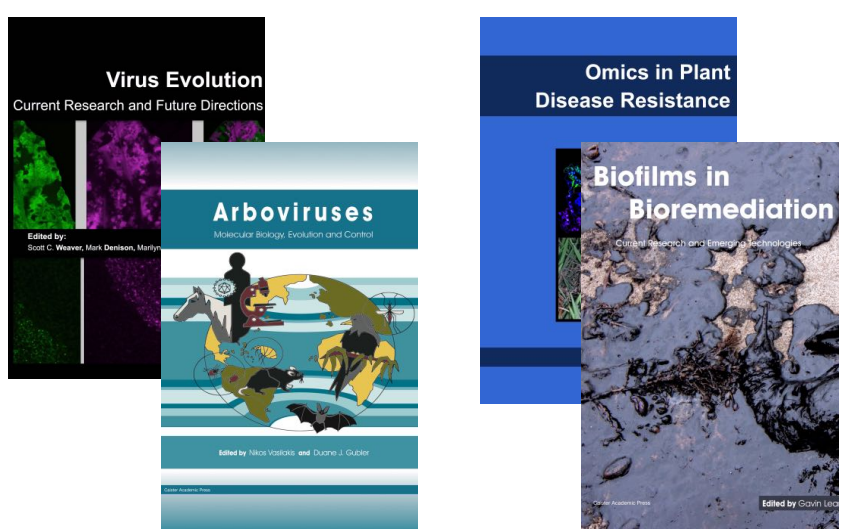
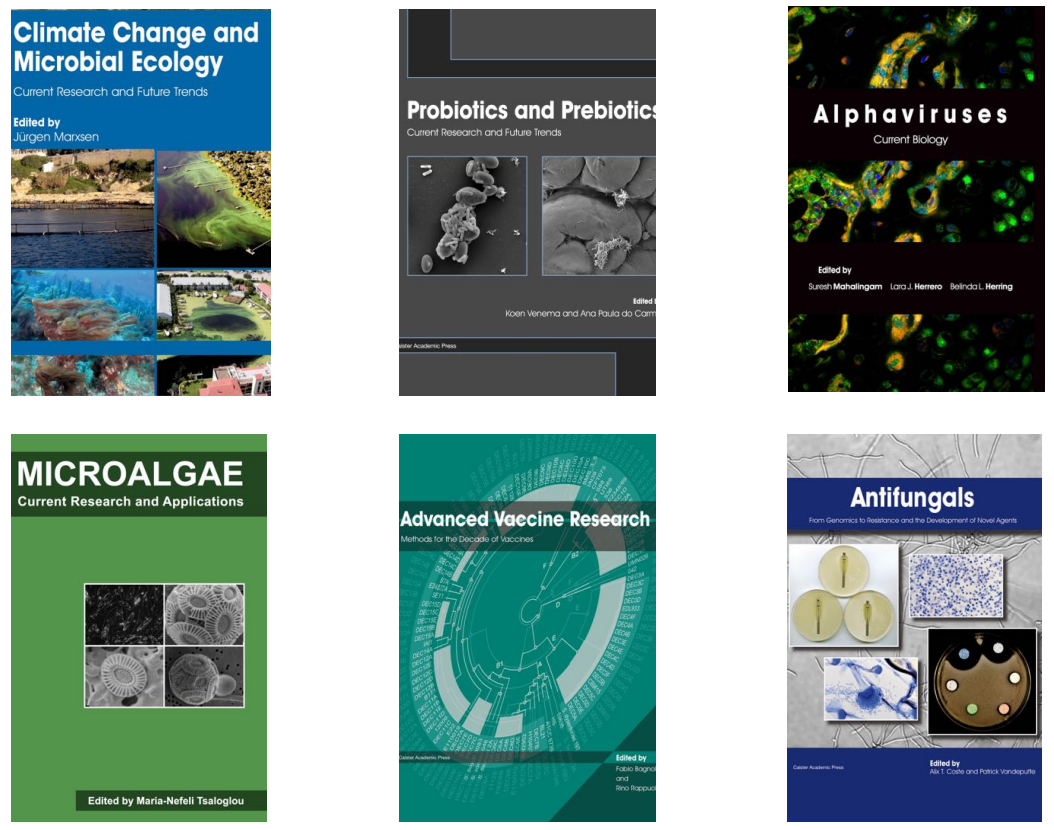

- Flow Cytometry in Microbiology: Technology and Applications Edited by: MG Wilkinson (2015) www.caister.com/flow

- Probiotics and Prebiotics: Current Research and Future Trends Edited by: K Venema, AP Carmo (2015) www.caister.com/probiotics

- Epigenetics: Current Research and Emerging Trends Edited by: BP Chadwick (2015) www.caister.com/epigenetics2015

- Corynebacterium glutamicum: From Systems Biology to Biotechnological Applications

Edited by: A Burkovski (2015)

www.caister.com/cory2

- Advanced Vaccine Research Methods for the Decade of Vaccines

Edited by: F Bagnoli, R Rappuoli (2015)

www.caister.com/vaccines

- Antifungals: From Genomics to Resistance and the Development of Novel Agents

Edited by: AT Coste, P Vandeputte (2015)

www.caister.com/antifungals

- Bacteria-Plant Interactions: Advanced Research and Future Trends Edited by: J Murillo, BA Vinatzer, RW Jackson, et al. (2015) www.caister.com/bacteria-plant

\section{- Aeromonas}

Edited by: J Graf (2015)

www.caister.com/aeromonas

- Antibiotics: Current Innovations and Future Trends

Edited by: S Sánchez, AL Demain (2015)

www.caister.com/antibiotics

- Leishmania: Current Biology and Contro Edited by: S Adak, R Datta (2015) www.caister.com/leish2

- Acanthamoeba: Biology and Pathogenesis (2nd edition) Author: NA Khan (2015)

www.caister.com/acanthamoeba2

- Microarrays: Current Technology, Innovations and Applications Edited by: Z He (2014)

www.caister.com/microarrays2

- Metagenomics of the Microbial Nitrogen Cycle: Theory, Methods and Applications

Edited by: D Marco (2014)

www.caister.com/n2 